\title{
The impact of urban air pollution exposure on the development of alterations on oxidative stress and behavioral parameters in adult mice
}

\author{
Karina Camasmie Abe*1, Leticia de Campos Brandao ${ }^{1}$, Sergio Tufik ${ }^{1}$, Paulo \\ Hilario do Nascimento Saldiva ${ }^{3}$ and Vania D'Almeida ${ }^{1,2}$
}

\author{
Address: ${ }^{1}$ Department of Psychobiology, Federal University of Sao Paulo, Sao Paulo, Brazil, ${ }^{2}$ Department of Health Sciences, Federal University of \\ Sao Paulo, Sao Paulo, Brazil and ${ }^{3}$ Department of Pathology, University of Sao Paulo, Sao Paulo, Brazil \\ * Corresponding author
}

\author{
from International Society on Brain and Behaviour: 3rd International Congress on Brain and Behaviour \\ Thessaloniki, Greece. 28 November - 2 December 2007 \\ Published: 17 April 2008 \\ Annals of General Psychiatry 2008, 7(SuppI I):SI 32 doi:I0.II86/I744-859X-7-SI-SI 32
}

This abstract is available from: http://www.annals-general-psychiatry.com/content/7/SI/SI32

(c) 2008 Abe et al.; licensee BioMed Central Ltd.

\section{Background}

The detrimental effects of air pollution on health have been recognized for most of the last century. It is well known that environmental conditions are related to the risk of developing cardiovascular and pulmonary diseases [1]. However, few studies involving other parameters are known, such as behavior and oxidative stress, which are the focus of investigation on the present study.

\section{Materials and methods}

Swiss male mice were daily exposed to the urban polluted air (pollution group) or filtered air (control group) for 3 months inside a special chamber, which reproduced a real exposure condition. We performed activity box and elevated plus-maze (EPM) as behavioral tests; and erythrocyte antioxidant defense parameters, including catalase, superoxide dismutase, glutathione peroxidase activities and total glutathione concentration. Statistical analysis were performed by student $\mathrm{t}$ test $(\mathrm{p}<0.05)$.

\section{Results}

In respect to motor activity, pollution group demonstrated significant increase of this parameter compared to control group, whereas on EPM test, the pollution group presented a significant decreased number of entries into the open arms. Moreover, air pollution could decrease significantly superoxide dismutase and glutathione peroxidase activities.

\section{Conclusions}

The results suggest that air pollution could affect diverse aspects of mice behavior. Indeed, air pollution was capable of decreasing the erythrocyte antioxidant defenses, suggesting an alteration on oxidative stress status.

\section{Acknowledgements}

We would like to thank FAPESP, CEPID and AFIP.

\section{References}

I. Schwartz J: Long-term effects of exposure to particulate air pollution. Clin Occup Environ Med 2006, 5:837-48. 